\title{
Path Analysis on the Determinants of Depression Symptom in Elderly: A PRECEDE PROCEED Model
}

\author{
Zela Tunurrohmin'), RB. Soemanto'), \\ Eti Poncorini Pamungkasari3) \\ 1)Masters Program in Public Health, Universitas Sebelas Maret \\ 2)Faculty of Social and Political Sciences, Universitas Sebelas Maret \\ 3)Faculty of Medicine, Universitas Sebelas Maret
}

\begin{abstract}
Background: Mental health problems such as depression get less attention. This is due to the stigma that depression and mental health are things that do not need special attention. The population with the highest level of depression in Indonesia is experienced by the elderly. Depression in the elderly is caused by health factors, loss of loved ones and peer support and family support. The purpose of this study was to analyze the determinants of depressive symptoms in elderly.

Subjects and Method: This was a cross sectional study conducted in Surakarta, Central Java, from September to October 2019. A sample of 200 elderly aged $>60$ years old was selected by cluster random sampling. The dependent variable was depressive symptoms. The independent variables were gender, education, employment status, marital status, residence, morbidity, family support, and peer support. The data were collected by questionnaire and analyzed by path analysis. Results: The risk of depressive symptoms in the elderly increased with the elderly who did not have a partner $(\mathrm{b}=8.42 ; 95 \% \mathrm{CI}=5.75$ to $11.1 ; \mathrm{p}<0.001)$, female gender $(\mathrm{b}=4.83 ; 95 \% \mathrm{CI}=2.38$ to 7.27; $\mathrm{p}<0.001)$, elderly who do not work $(\mathrm{b}=2.85 ; 95 \% \mathrm{CI}=0.32$ to $5.38 ; \mathrm{p}=0.027)$, have morbidity $(b=12.53 ; 95 \% \mathrm{CI}=0.16$ to $4.89 ; \mathrm{p}=0.036)$. The risk of depressive symptoms in the elderly decreased with strong peer support $(b=-2.79 ; 95 \% C I=-5.01$ to $-0.56 ; p=0.014)$, strong family support $(\mathrm{b}=-8.67 ; 95 \% \mathrm{CI}=-11.38$ to $-5.97 ; \mathrm{p}<0.001)$. The risk of depressive symptoms was indirectly affected by education and residence

Conclusion: The risk of depressive symptoms in the elderly increases with the elderly who do not have partners, gender, employment status, and morbidity. The risk of depressive symptoms in the elderly decreases with peer support, family support. The risk of depressive symptoms is indirectly affected by education and residence.
\end{abstract}

Keywords: depression symptoms, elderly

\section{Correspondence:}

Zela Tunurrohmin. Masters Program in Public Health, Universitas Sebelas Maret. Jl. Ir. Sutami 36A, Surakarta, Central Java, Indonesia. Email: ze.zelatunurrohmin@gmail.com. Mobile: 082225442002

\section{BACKGROUND}

Depression is a mood disorder characterized by lethargy and decreased thinking power that can be accompanied by symptoms of psychomotor retardation including loss of interest in normal activities. This is due to a decrease in social status, increasing age, and other environmental factors (Zhang, 2018).
The total estimated number of people in the world living with depression increased by $18.4 \%$ between 2005 and 2015 (WHO, 2017). An increase in depression sufferers also occurs in Indonesia. Data on the prevalence of elderly aged 55-64 years who experience depression by $15.9 \%$, elderly aged $65-74$ years by $23.2 \%$, and elderly people over 75 years by $33.7 \%$ (Ministry of 
Health, 2013). The prevalence of elderly people in Central Java who experience depression is $12 \%$. Elderly aged 55-64 years by $14.2 \%$, elderly aged $65-74$ by $18.0 \%$, elderly aged $>75$ years by $28.7 \%$ (Livana, 2018).

Factors that cause depression are artificially divided into biological, genetic and psychosocial factors (Kaplan in Santoso, 2017). Another psychosocial factor is the environment in which among elderly workers in rural areas, the effect of work stress on depressive symptoms depends on family debt and the level of their environmental cohesion (Feisun, 2019).

Mental health problems such as depression and stress get less attention from health care professionals or from the elderly because of the stigma that depression and other mental health are things that do not need special attention (WHO, 2017).

Thus the increase in the number of people with depression is not offset by significant treatment efforts. This shows that, of the total Depression sufferers, only 9\% treated (Ministry of Health, 2018).

\section{SUBJECTS AND METHOD \\ 1. Study Design \\ This was an analytic observational study with a cross sectional design. The study was conducted in Surakarta, Central Java, from September-October 2019.}

\section{Population and Sample}

The population in this study were elderly aged $>60$ years old. A sample of 200 elderly was selected for this study by cluster random sampling.

\section{Study Variables}

The dependent variable was depressive symptom. The independent variables were gender, education level, employment status, marital status, residence, morbidity, family support, and peer support.

\section{Operational Definition of Variables} Depressive symptom was mental disorders related to the natural feelings of sadness and accompanying symptoms, including fatigue, hopelessness, and helplessness. The data were collected by questionnaire. The measurement scale was continous.

Gender was an individual difference based on sex or gender. The data were collected by questionnaire. The measurement scale was categorical, coded o for male and 1 for female.

Education was a formal education ever pursued by subjects, based on the last diploma they have. The data were collected by questionnaire. The measurement scale was categorical, coded o for $<$ Senior high school and 1 for $\geq$ Senior high school.

Employment was a routine activity carried out as an effort to get income to meet the needs. The data were collected by questionnaire. The measurement scale was categorical, coded o for employed and 1 for unemployed.

Marital Status was a marital status that is categorized in the form of not/ not yet married/ married and divorced/ widowed/ widower. The data were collected by questionnaire. The measurement scale was categorical, coded o for having a partner and 1 for not having a partner.

Residence was the address and type of daily residence of the subjects residing. The data were collected by questionnaire. The measurement scale was categorical, coded o for living at home and 1 for living at Werdha Nursing Home.

Family support was any form of support provided by the family to reduce the tendency for depression in the elderly. The data were collected by questionnaire. The measurement scale was continous and transformed into dichotomous, coded o for weak and 1 for strong. 
Peer Support was any form of support provided by peers to reduce the tendency for depression in the elderly. The data were collected by questionnaire. The measurement scale was continous and transformed into dichotomous, coded o for weak and 1 for strong

\section{Data Analysis}

Univariate analysis was used for characteristics. Continuous data samples are described in $\mathrm{n}$, mean, standard deviation (SD), minimum and maximum. The sample and categorical characteristics are described in $\mathrm{n}$ and\%.

The bivariate analysis used in this study was the t test with effect size. Multivariate analysis in this study was carried out using the path analysis method. Path analysis is a multivariate procedure that can be used for continuous, discrete, or

Table 1. Subjects Characteristics

\begin{tabular}{|c|c|c|}
\hline Characteristics & $\mathbf{n}$ & Percentage \% \\
\hline \multicolumn{3}{|l|}{ Gender } \\
\hline Male & 83 & 41.5 \\
\hline Female & 117 & 58.5 \\
\hline \multicolumn{3}{|l|}{ Education } \\
\hline$<$ Senior high school & 130 & 65.0 \\
\hline$\geq$ Senior high school & 70 & 35.0 \\
\hline \multicolumn{3}{|l|}{ Employment Status } \\
\hline Working & 53 & 26.5 \\
\hline Not working & 147 & 73.5 \\
\hline \multicolumn{3}{|l|}{ Marital Status } \\
\hline Married & 74 & 37.0 \\
\hline Single & 126 & 63.0 \\
\hline \multicolumn{3}{|l|}{ Residence } \\
\hline House & 100 & 50.0 \\
\hline Panti Werdha & 100 & 50.0 \\
\hline \multicolumn{3}{|l|}{ Morbidity } \\
\hline No & 48 & 24.0 \\
\hline Yes & 152 & 76.0 \\
\hline \multicolumn{3}{|l|}{ Family Support } \\
\hline Weak & 90 & 45.0 \\
\hline Strong & 110 & 55.0 \\
\hline \multicolumn{3}{|l|}{ Peers Support } \\
\hline Weak & 77 & 38.5 \\
\hline Strong & 123 & 61.5 \\
\hline
\end{tabular}

dichotomous data. Path analysis explains the causal relationships of variables with the help of a path diagram.

\section{Research Ethics}

This study was conducted based on research ethics, namely informed consent, anonymity, confidentiality, fairness and benefits. Ethics permission in this study was obtained from the Health Research Ethics Commission Dr. Moewardi Hospital, Surakarta, Indonesia, No. 1,068/IX/HREC /2009.

\section{RESULTS}

\section{Samples Characteristics}

Characteristics of the sample in this study are gender and education. Sample characteristics of categorical data was described in Table 1. Sample characteristics of continous data described in Table 2. 
Journal of Epidemiology and Public Health (2019), 4(4): 351-360

https://doi.org/10.26911/jepublichealth.2019.04.04.10

\section{Univariate Analysis}

Table 2. Description of research variables with continuous data

\begin{tabular}{lccrcc}
\hline \multicolumn{1}{c}{ Independent Variables } & N & Mean & SD & Min. & Max. \\
\hline Family Support & 200 & 14.17 & 11.63 & 0 & 32 \\
Peers Support & 200 & 20.87 & 6.52 & 6 & 32 \\
Depression Symptoms & 200 & 28.82 & 13.29 & 3 & 60 \\
\hline
\end{tabular}

\section{Bivariate Analysis}

Bivariate analysis explains the relationship of one independent variable to the dependent variable. The bivariate analysis used in this study was the $t$ test with the effect size calculation. $T$ test is used to test the dependent variable with continous data and independent variables with categorical data.

Table 3 showed that there is a negative influence between gender and depressive symptoms. So that it can be interpreted that male subjects reduces the risk of depressive symptoms with a high effect (effect size $=-1.97 ; \mathrm{p}<0.001$ ).

There is a positive influence between education and depressive symptoms. Elderly with education <senior high school increased the risk of depressive symptoms (effect size $=1.57$; $\mathrm{p}<0.001$ ).

There is a negative influence between work status and depressive symptoms. Elderly people who work reduce the risk of depressive symptoms with a high effect (effect size $=-1.79 ; p<0.001$ ).

There is a negative influence between the residence with symptoms of depression. Elderly who live at home reduce the risk of depressive symptoms with a high effect (effect size $=-2.44 ; \mathrm{p}<0.001$ ).

There is a negative influence between morbidity and depressive symptoms. Elderly who did not experience morbidity reduced the risk of depressive symptoms with a high effect (effect size $=-1.40 ; \mathrm{p}<0.001$ )

There was a positive influence between family support with depressive symptoms. Elderly with weak family support increased the risk of depressive symptoms with a high effect (effect size = 2.64; $\mathrm{p}<0.001$ ).

There was a positive influence between peer support and depressive symptoms in the elderly with weak peer support increasing the risk of depressive symptoms with a high effect (effect size $=$ 1.55; $\mathrm{p}<0.001$ ).

There is a negative influence between the family's economic status and depressive symptoms. Elderly with the family's economic responsibility as being borne reduced the risk of depressive symptoms with a high influence (effect size $=-1.18$; $p$ $<0.001$ )

There is a negative influence between marital status and depressive symptoms. Elderly people who have a partner reduce the risk of depressive symptoms with a high effect (effect size $=-2.55 ; \mathrm{p}<0.001$ ).

\section{Multivariate Analysis}

Multivariate analysis was performed using the path analysis method) using Stata 13. Path analysis examined the relationships between independent and dependent variables direct and indirectly.

Table 4 showed that depression symptom was directly affected by marital status, gender, employment status, peer support, and family support.

Table 4 showed that marriage status was associated with depressive symptom. Unmarriage or divorced elderly was directly and positively associated with depressive symptom $(b=8.42 ; 95 \% \mathrm{CI}=5.75$ to 11.1 ; $\mathrm{p}<0.001)$. 
Table 3. Bivariate analysis of depressive symptoms in elder age

\begin{tabular}{lccc}
\hline & n & Effect size & p \\
\hline Gender (Male) & 200 & -1.97 & $<0.001$ \\
Education (<Senior high school) & 200 & 1.57 & $<0.001$ \\
Employed & 200 & -1.79 & $<0.001$ \\
High income & 200 & -1.18 & $<0.001$ \\
Marital Status (Married) & 200 & -2.55 & $<0.001$ \\
Residence (House) & 200 & -2.44 & $<0.001$ \\
Morbidity (Yes) & 200 & -1.40 & $<0.001$ \\
Family Support (Weak) & 200 & 2.64 & $<0.001$ \\
Peers Support (Weak) & 200 & 1.55 & $<0.001$ \\
\hline
\end{tabular}

Table 4. The results of the path analysis on the effect of family and peer support on the quality of life of the elderly

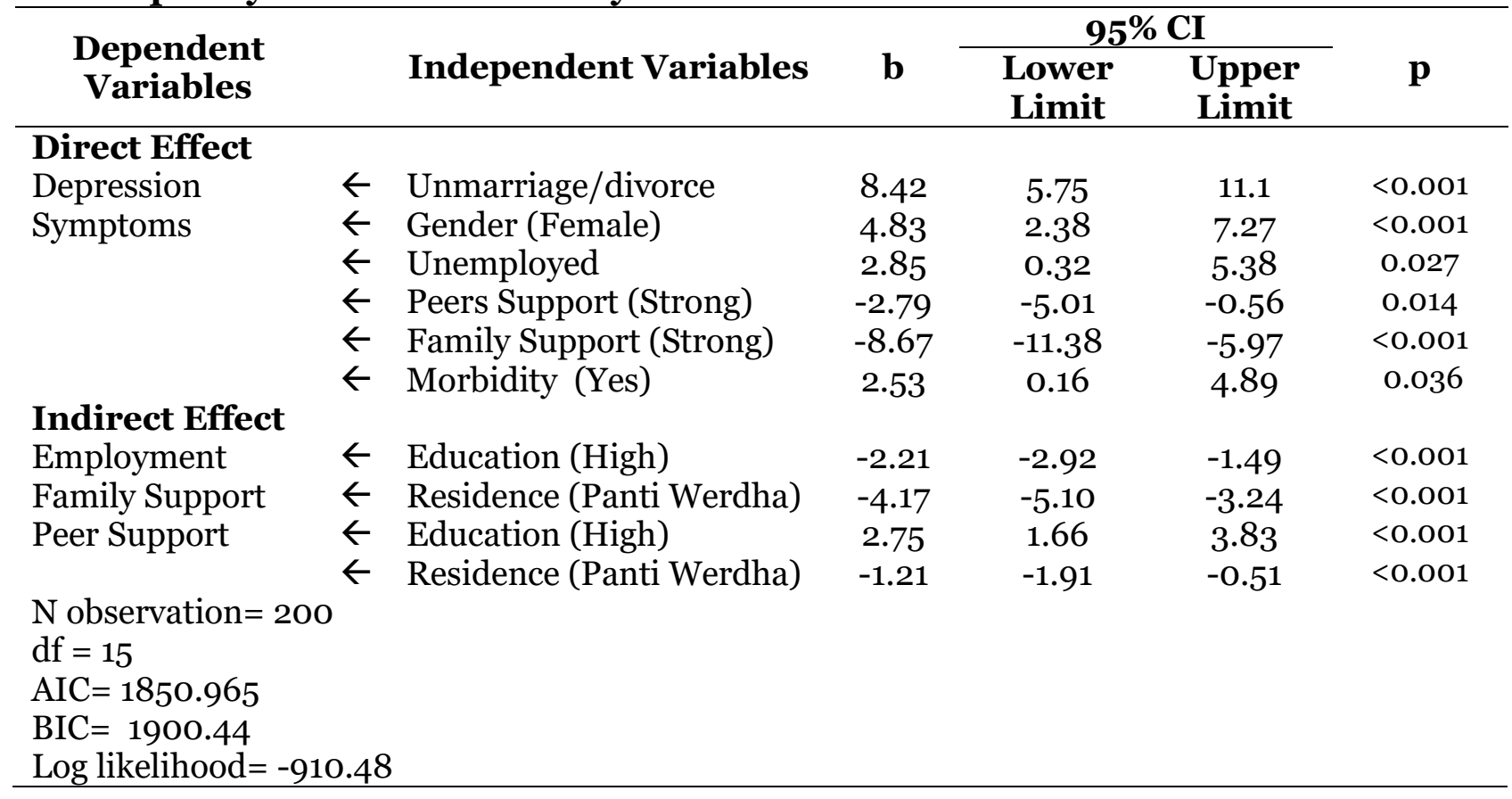

Gender was directly and positively associated with depressive symptom. Female elderly had logodd for experiencing depressive symptom 4.83 units higher than male $(b=4.83 ; 95 \% \mathrm{CI}=2.38$ to 7.27 ; $\mathrm{p}<0.001)$.

Employment was directly and positively associated with depressive symptom. Unemployment elderly had logodd to experience depressive symptom 2.85 units higher than those worked $(b=2.85 ; 95 \%$ $\mathrm{CI}=0.32$ to $5.38 ; \mathrm{p}=0.027$ ).

Peer support was directly and negatively associated with depressive symptom. Elderly with strong peer support were less likely to experience depressive symptom. Elderly with strong peer support has logodd to experience depressive symptoms 2.79 units lower than weak peer support $(\mathrm{b}=$ 2.79; $95 \% \mathrm{CI}=-5.01$ to $-0.56 ; \mathrm{p}=0.014)$.

Family support was directly and negatively associated with depressive symptom. Elderly with strong family support had logodd to experience symptoms of depression 8.67 units lower than weak family support $(b=-8.67 ; 95 \% \mathrm{CI}=-11.38$ to -5.97 ; $\mathrm{p}<0.001$ ).

Morbidity was directly and positively associated with depressive symptom. Elderly with morbidity had logodd to experience 
depressive symptom 2.53 units higher than those without morbidity $(b=12.53 ; 95 \%$ $\mathrm{CI}=0.16$ to $4.89 ; \mathrm{p}=0.036$ ).

Depression symptom in elderly was indirectly affected by education and employment through occupation, family support, and peer support.

Employment status was negatively associated with education $(\mathrm{b}=-2.21 ; 95 \%$ $\mathrm{CI}=-2.92$ to $-1.49 ; \mathrm{p}<0.001)$.
Family support status was negatively associated with residence $(b=-4.17 ; 95 \%$ $\mathrm{CI}=-5.10$ to $3-3.24 ; \mathrm{p}<0.001$ ).

Peer support was positively associated with education $(\mathrm{b}=2.75 ; 95 \% \mathrm{CI}=1.66$ to 3.83; $\mathrm{p}<0.001$ ).

Peer support was negatively associated with residence $(b=-1.21 ; 95 \% \mathrm{CI}=-$ 1.91 to $-0.51 ; \mathrm{p}<0.001$ ).

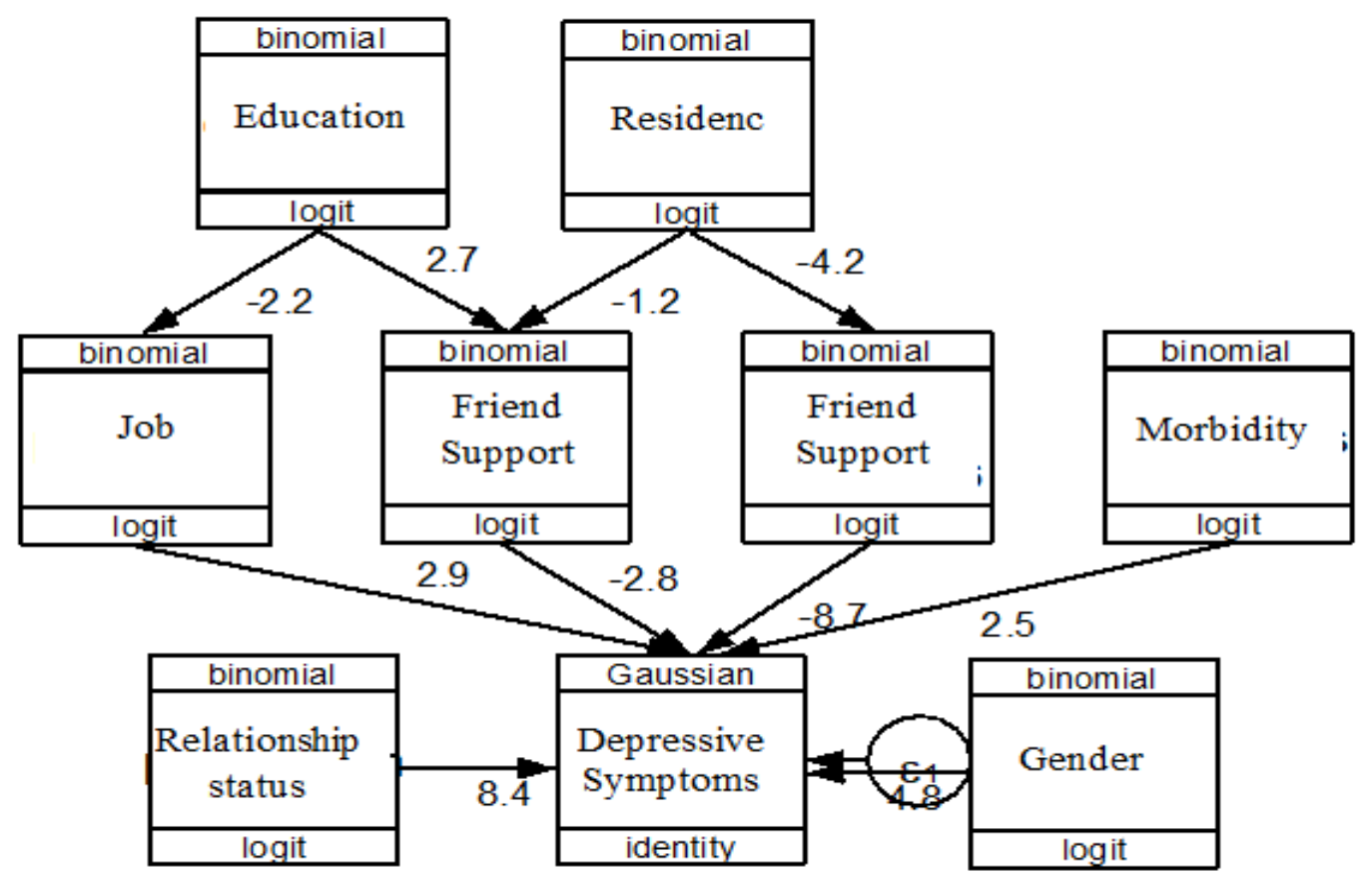

Figure 1. Path analysis of the determinants of depressive symptoms in the elderly

Older people who have higher education are more likely to get stronger peer support so that they are less likely to experience symptoms of depression. Older people with high education have the logodd to get strong peer support 2.75 units higher than those with low education $(b=2.75$; $95 \% \mathrm{CI}=1.66$ to 3.83 ; $\mathrm{p}<0.001$ ).

Older people living in Werdha homes have a smaller chance of getting strong peer support so that they are more likely to experience symptoms of depression. Elderly people living in Werdha homes have the logodd to have strong peer support 1.21 units lower than those living at home $(\mathrm{b}=-$ $1.21 ; 95 \% \mathrm{CI}=-1.91$ to $-0.51 ; \mathrm{p}=0.066)$.

\section{DISCUSSION}

1. The effects of education on depression symptoms in elderly

Education is an indirect factor from occupation on depressive symptoms in old age. Older people with high education have a greater likelihood of getting a good job, so they are less likely to experience symptoms of depression. Older people with higher education have the logodd to experience symptoms of depression 2.21 units lower 
than low education. The results of this study are consistent with studies that have been conducted in China with results that indicate that higher education and high levels of income have a lower likelihood of experiencing depression, especially among lower socioeconomic groups (Qin et al, 2018).

A study by Abella shows the same results as the results of this study, namely the existence of socioeconomic influences, especially education on depression through work. This is because the higher the education there will be the effect of the higher one's position or income in the workforce. So, the risk of experiencing symptoms of depression will be lower (Abella et al., 2018). The size of the income and the level of position will affect the benefits and activities of someone in the elderly.

Education is also an indirect influence through peers support for depression symptoms in old age. Older people with high education have a greater chance of getting support from peers so that they are less likely to experience symptoms of depression. This is in line with the PRECEDE PROCEED theory which explains the relationship between predisposing factors through Reinforcing factors that will influence the occurrence of a behavior (Hamidi, 2019). This happens because PRECEDE PROCEED which explains the predisposing factor relationship in this study is education through Reinforcing factor, namely peer support that will influence the occurrence of depressive behavior.

\section{The effects of gender on depress- ion symptoms in elderly}

Gender has a direct influence on depressive symptoms in older age. Elderly women has a greater likelihood of experiencing symptoms of depression. This is in accordance with previous studies with the result that there is a significant difference between de- pression in elderly men and elderly women, where women have a higher depression compared with male sex (Lotfaliany et al., 2019).

Women have a higher chance than men due to the characteristics of women who prioritize emotional rather than rational, easier to feel guilty and easily anxious (Pitayanti, 2016). With the emotional higher than rational causes, women are more prone to experience things that are not in accordance with their desires, so it will be more likely to experience stress opportunities that will lead to depression.

\section{The effect of marriage on depress- ion symptoms in elderly}

Marriage has a direct effect on depressive symptoms in older age. Older people who are single have a greater risk of depressive symptoms. These results are in line with previous research which result that factors related to loneliness and depression separately ie not married (never married, separated, divorced or widowed) have a higher chance of depression (Domenech et al., 2017).

Having a partner and not having a partner have an influence on the occurrence of depressive symptoms in the elderly because, when an elderly person still has a life partner then someone will pay attention. Thus the psychological needs will be met which leads to the spirit of life and prevent depressive symptoms. Previous studies have shown that respondents who do not have a partner experience depression due to lack of support from the family, what else is the couple so that the emotional level is not controlled so that respondents experience depression (Alini, 2017).

4. The effect of employment status on depression symptoms in elderly

Occupation has a direct effect on the symptoms of older age depression. Older people who do not work are more likely to 
experience symptoms of depression. Elderly who do not work have the logodd to experience symptoms of depression 2.85 units higher than those who work. This result is in accordance with previous study which is based on employment status, respondents who do not work have a higher proportion of depression that is as many as 16 people (25.4\%), while among respondents who are still working who experience depression only amounting to 5 people (18.5\%) (Aryawangsa , 2016).

Elderly people who work have a lower possibility of depression, this is because older people who work still have their own income. Therefore, in meeting the needs of his life does not depend on giving other people. When an elderly person has a job and can meet his needs with his own results, it will reduce stress that leads to depression.

\section{The effect of residence on symp- toms of depression in elderly}

Residence has an indirect effect through family support for depression symptoms in older age. Elderly people living at the Werdha Nursing Home are less likely to get family support so they are more likely to experience symptoms of depression. Elderly people living in nursing homes in Werdha have a logodd to experience depressive symptoms -4.17 units higher than staying at home. The results of this study are in accordance with previous studies that there is a significant relationship between family support and the incidence of depression in the elderly. The higher the family supports the lower the incidence of depression in the elderly (Utari, 2015).

Residence has an indirect effect through peers support for symptoms of depression in the elderly. Older people living in nursing homes in Werdha are less likely to get strong peer support, so they are more likely to experience symptoms of severe depression. The elderly who live in the Werdha home have the logodd to have strong peer support - 1.21 units lower than those living at home.

\section{The effects of morbidity on de- pression symptoms in elderly}

There was a direct effect of morbidity on depressive symptoms in old age. Older people with morbidity are more likely to experience symptoms of depression. Older people with morbidity have logodd to experience depressive symptoms 2.53 units higher than those without morbidity. This is in accordance with the PRECEDE PROCEED theory which explains Reinforcing factors that will influence the occurrence of a behavior (Hamidi, 2019).

\section{The effect of family support on symptoms of depression in elderly}

Family support has a direct influence on depressive symptoms in old age. Older people with strong family support are less likely to experience symptoms of depression. Elderly people with strong family support had the logodd to experience symptoms of depression 8.67 units lower than weak family support. These results are in accordance with previous research that wa respondents who got a bad family role had a risk of 215.54 times experiencing depression compared to respondents who got a good family role (Personal, 2017).

\section{The effect of peers support on symptoms of depression in elderly}

Peers support has a direct effect on depressive symptoms in old age. Old age with the support of strong friends are less likely to experience symptoms of depression. Elderly with strong friend support has logodd to experience symptoms of severe depression 2.79 units lower than weak friend support. This result is in accordance with previous research, that social support is very influential on the incidence of depression, when social support is weak, the 
higher the elderly experience symptoms of depression (Zhao et al., 2018).

\begin{tabular}{l} 
AUTHOR CONTRIBUTION \\
\hline Zela Tunurrohmin as the main author \\
collected the data, wrote the article, and \\
analyzed the data. RB. Soemanto suggested \\
the materials for background and discuss- \\
ion. Eti Poncorini Pamungkasari formu- \\
lated of theoretical framework.
\end{tabular}

\section{FUNDING AND SPONSORSHIP}

This study is self-funded.

\section{CONFLICT OF INTEREST}

There is no conflict of interest in this study.

\section{ACKNOWLEDGEMENT}

Acknowledgments were conveyed by researchers to the Head of the Health Service, Social Service and Head of the Surakarta City Nursing Home for allowing this research to be carried out. We also thank all the elderly who have been willing and cooperative to become research respondents.

\section{REFERENCE}

Alini (2016). Faktor-faktor yang berhubungan dengan kejadian depresi pada lansia di posyandu lansia desa jake wilayah kerja uptd kesehatan kari kabupaten kuantan singingi tahun 2016 (Factors related to the incidence of depression in the elderly in the elderly Posyandu village Jake working area UPDD Health Curry Kuantan District 2016). 1(1):1. Jurnal Ners Universitas Pahlawan Tuanku Tambusai. Retrieved from https://journal.universitaspahlawan.ac.id/ind ex.php/ners/article/view/82

Aryawangsa AAN, Ariastuti NLP (2015). Prevalensi dan distribusi faktor risiko depresi pada lansia di wilayah kerja Puskesmas Tampaksiring I Kabupaten Gianyar Bali 2015 (Prevalence and distribution of depression risk factors in the elderly in Tampaksiring I Health Center, Gianyar Regency, Bali 2015). 7(1): 2089-9084. Retrieved from https://isainsmedis.id/index.php/ism/article/viewFile/7/8

Domnech-Abella J, Lara E, Rubio, Valera M, Olaya B, Moneta MV, Rico LA, Haro JM (2017). Loneliness and depression in the elderly: the role of social network. Social Psychiatry and Psychiatric Epidemiology, 52(4):381390. https://doi.org/10.1007/s00127017-1339-3

Domenech J, Mundo J, Leonardi M, Chatterji S, Tobiasz B, Koskinen JM (2018). The association between socioeconomic status and depression among older adults in Finland, Poland and Spain: A comparative cross-sectional study of distinct measures and pathways. JOAD, 2(4); 311-318. Https://doi.org/10.1016/j.jad.2018.08.07 7.

Hamidi, Rahardjo, Wijaya (2019). Path analysis on the determinants of adherence to anti tuberculosis drug treatment in Kaur district, Bengkulu, Indonesia. J Epidemiol Community Health. 4(3): 205-214. https://doi.org/10.26911/jepublichealth.2019.04.03.0 8.

Feisun (2019). Depressive symptoms in three Chinese older workforce group : the interplay of work stress with family and community factors. International psychogeriatrics. 4(2): 15-21. doi: 10.1017/S1041610219000528

Ministry of Health RI (2013). Riset Kesehatan dasar dalam angka Provinsi Jawa Tengah. Badan Penelitian dan Pengembangan Kesehatan (Basic 
Journal of Epidemiology and Public Health (2019), 4(4): 351-360

https://doi.org/10.26911/jepublichealth.2019.04.04.10

Health Research in Numbers in the Province of Central Java. Health Research and Development Agency). Retrieved from https://terbitan.litbang.depkes.go.id/penerbitan/index. $\mathrm{php} / \mathrm{lpb} /$ catalog/book/94

Ministry of Health RI (2018). Data dan Informasi Profil Kesehatan Indonesia 2018 (Indonesia Health Profile Data and Information in 2018). Kementerian Kesehatan Badan penelitian dan Pengembangan Kesehatan. Retrieved from https://pusdatin.kemkes.go.id/folder/view/o1/structurepublikasi-data-pusat-data-dan-informasi.html

Livana YS, Lestari ED, Anggraeni (2018). Gambaran tingkat depresi lansia (Overview of depression in the elderly). Jurnal Keperawatan dan Pemikiran Ilmiah. 4(4): 80-93. Retrieved from http://jurnal.unissula.ac.id/index.php/jnm/article/download/3936 $/ 2798$

Lotfaliany M, Hoare E, Jacka FN, Kowal P. Berk M, Mohebbi, M (2019). Variation in the prevalence of depression and patterns of association, sociodemographic and lifestyle factors in community-dwelling older adults in six low- and middle-income countries. JOAD. 251(1):218-226. https://doi.org/10.1016/j.jad.2019.01.054

Pitayanti (2017). Perbedaan depresi antara pria dan wanita di posyandu lansia desa winonggo madiun (Differences in depression between men and women in the elderly Posyandu in Winonggo Madiun village). Jurnal Keperawatan \& Kebidanan - Stikes Dian
Husada Mojokerto. Retrieved from https://jurnalonline.lppmdianhusada.ac.id/index.php/jkk/article/view/6 5.

Qin X, Wang S, Hsieh CR (2018). The prevalence of depression and depressive symptoms among adults in China: estimation based on a National Household Survey. China Economic Review. Elsevier 51: 271-282. https://doi.org/10.1016/j.chieco.2016.04.001.

Santoso MB, Asiah DH, Kirana CI (2017). Bunuh diri dan depresi dalam perspektif pekerjaan sosial. Prosiding penelitian \& pengabdian kepada masyarakat. jurnal.unpad. 4(3): 390-447. Retrieved from http://jurnal. unpad.ac.id/prosiding/article/view/18617

Utari W (2015). Hubungan dukungan keluarga dengan tingkat depresi pada lansia. Jurnal Ilmiah STIKES Kendal, 5(1):22-28. Retrieved from http://journal.stikeskendal.ac.id/index.php/ PSKM/article/view/110.

World Health Organization (2017). Depression and other common mental disorders mental health. https://creativecommons.org/licenses/by-ncsa/3.0/igo).

Zhang Y, Chen Y, Ma L (2018). Depression and cardiovascular disease in elderly: Current understanding. J CLIN NEUROSCI. 47(1):1-5. https://doi.org/10.1016/jjocn.2017.09.022. 